PROFESSOR CHRISTIAN SUE (Orcid ID : 0000-0002-2472-5001)

MISS VANESA BARBERON (Orcid ID : 0000-0002-3186-8289)

Article type : Research Article

\title{
SEISMOTECTONIC IMPLICATIONS OF THE SOUTH CHILE RIDGE SUBDUCTION BENEATH THE PATAGONIAN ANDES
}

Rodrigo Suárez (a), Christian Sue (b,c), Matías Ghiglione (a), Benjamin Guillaume (d), Miguel Ramos (a), Joseph Martinod (b), Vanesa Barberón (a)

a) Instituto de Estudios Andinos (Universidad de Buenos Aires - CONICET), Buenos Aires, Argentina.

b) ISTerre, CNRS, IRD, Université Grenoble Alpes, Université de Savoie Mont-Blanc, Le Bourget du Lac, France.

c) UMR6249, Université de Bourgogne Franche-Comté, Besançon, UFC, France.

d) Université Rennes, CNRS, Géosciences Rennes - UMR 6118, F-35000, Rennes, France.

* Corresponding author: Rodrigo Javier Suárez. Instituto de Estudios Andinos IDEAN (Universidad de Buenos Aires - CONICET). Intendente Güiraldes 2160, Ciudad Universitaria - Pabellón II C1428EGA - CABA Argentina. Institutional e-mail: rsuarez@gl.fcen.uba.ar; Personal e-mail: rodrigo_s_37@hotmail.com

\section{STATEMENT OF SIGNIFICANCE}

The formation of a slab window beneath the Patagonian Andes produces physicalchemical disturbances on the upper plate. We address how intraplate seismicity and tectonic stress regime distribute in this peculiar tectonic setting. The seismotectonic

This article has been accepted for publication and undergone full peer review but has not been through the copyediting, typesetting, pagination and proofreading process, which may lead to differences between this version and the Version of Record. Please cite this article as doi: $\underline{10.1111 / \text { TER.12521 }}$

This article is protected by copyright. All rights reserved 
implications that arise from this study could be useful to understand the environments of trench-ridge intersection around the world.

Abstract. The South Chile ridge (SCR) intersects the Patagonian trench around $46^{\circ}$ 09'S, forming the triple junction among the Antarctic, Nazca, and South America plates. Subduction of the SCR since $\sim 18$ Ma produced the opening of a slab window beneath Patagonia and a noticeable magmatic gap in the cordillera, profuse volcanism, and topographic uplift in the retroarc. To study seismicity distribution and present-day stress resulting from this particular framework, we analyze databases of seismic events and earthquake focal mechanisms. Our study finds that clusters of intraplate crustal seismic events are disrupted by a $\sim 450-470 \mathrm{~km}$ seismicity gap above the slab window. Calculated stress tensors depict a strike-slip tectonic regime north of the triple junction, and $\sim \mathrm{W}-\mathrm{E}$ compression to the south of the seismic gap. We propose that the seismotectonic behavior of the upper plate is disturbed at the first order by the trenchridge intersection, leading to a heterogeneous stress field.

Keywords. Earthquake focal mechanism; South Chile ridge; Patagonia slab window; Intraplate seismic gap. 


\section{INTRODUCTION}

The Andean chain is the locus of active seismicity driven by plate boundary forces, and although the overall result is a long-lasting orogenic belt, stress tectonic regimes are variable (Zoback, 1992) and the distribution of earthquakes depends on the configuration of the subducting oceanic plate for each segment (Levin and Sasorova, 2009; Bilek, 2010). High-magnitude earthquakes are nucleated at plates interface (e.g., Valdivia earthquake, 1960, Mw=9.5; Maule earthquake, 2010, Mw=8.8) and within the South America Plate (e.g., Aysén fjord earthquake, 2007, Mw=6.2). The southern Patagonian segment affected by a noticeable and well-studied magmatic gap related to the subduction of the South Chile ridge appears as a quieter region in terms of significant seismicity (Fig. 1; Cembrano et al., 2007; Perucca and Bastias, 2008; Petersen et al., 2018; Santibáñez et al., 2019). Previous studies have shown that the distribution of seismicity is influenced by ocean slab dip angles, but also by the presence of subducting features along the margin, such as fracture zones or aseismic and seismic ridges (e.g., Bilek, 2010).

Compilation of seismological data characterizes the South Patagonian Andes as a segment of an intraplate seismic gap that roughly coincides with the location of the asthenospheric slab window that started opening during Miocene subduction of the South Chile ridge (SCR) parallel to the trench (Fig. 1). Interestingly, this region is also characterized by a volcanic arc gap (DeLong et al., 1979; Stern, 2004), Neogene basaltic volcanism in the retroarc (Ramos and Kay, 1992; Gorring et al., 1997), and topographic uplift (Guillaume et al., 2009, 2010; Ávila and Dávila, 2020) as secondary and highly inter-related processes linked to South Chile ridge subduction and ensuing opening of an asthenospheric window.

Our study aims to uncover the effects of subduction of the South Chile ridge on seismic behavior and the present-day stress regime of the upper plate. We analyze seismicity distribution from global and local networks and earthquake focal mechanisms to study the associated tectonic stress regime along the Patagonian Andes. We show that the subduction of the SCR plays a major role in switching on/off the occurrence of significant tectonic seismicity as well as modifying the tectonic stress regime. 


\section{GEOMETRIC AND KINEMATIC EVOLUTION OF THE CHILE TRIPLE JUNCTION}

During the late Cenozoic plate convergence history (Somoza and Ghidela, 2012) an unstable quadruple junction developed between the Phoenix, Nazca, and Antarctic oceanic plates and the southernmost South American continent at around $\sim 18 \mathrm{Ma}$ (Breitsprecher and Thorkelson, 2009). Since $17 \mathrm{Ma}$, a series of trench-parallel segments of the SCR subducted beneath the southern Patagonian Andes, producing an overall northward migration of the Chile Triple Junction (CTJ), to finally reach its current position west of the Taitao Peninsula around 46 09'S (Figs. 1, 2; Cande and Leslie, 1986; Tebbens et al., 1997; Bourgois et al., 2000, 2016; Breitsprecher and Thorkelson, 2009).

This configuration produces highly contrasting plate scenarios: while South of the CTJ the Antarctic plate has an almost orthogonal $\sim \mathrm{E}-\mathrm{W}$ convergence direction at $\sim 2 \mathrm{~cm} / \mathrm{yr}$, North of the junction, the Nazca plate has an $\mathrm{N}-80^{\circ}$ direction oblique to the trench, at velocities four times faster ( 8,4 cm/yr; NUVEL-1A model, DeMets et al., 1990, 1994).

As a consequence of the velocity difference between subducted oceanic plates an asthenospheric slab window opened underneath southern Patagonia, so-called Patagonia slab window (PSW; Figs. 1, 2), as geometrically reconstructed by plate kinematic models (Breitsprecher and Thorkelson, 2009) and observed in tomographic images (Russo et al., 2010). This slab window triggers an anomalous surface heat flow on the continental plate (Ávila and Dávila, 2018), extensional tectonics on internal portions of the orogenic belt (Lagabrielle et al., 2007, Scalabrino et al., 2010, 2011), regional uplift either dynamic (Guillaume et al., 2009, 2010; Pedoja et al., 2011) or isostatic (Ávila and Dávila, 2020) of the extra-Andean region, and a switch from calcalkaline arc-magmatism to retroarc plateau basaltic lavas (Ramos and Kay, 1992; Gorring et al., 1997).

\section{METHODOLOGY}

\subsection{Dataset and definition of seismic regions for stress inversion}

We compiled a regional dataset of seismic events and fault-plane solutions of earthquakes along the Patagonian Andes (Figs. 1, 3, 4). Shallow seismic events at less than $70 \mathrm{~km}$ depth for the 1979-2019 period were downloaded from the USGS catalog 
(earthquake.usgs.gov/earthquakes). Data coverage above the Patagonia slab window was enhanced with a local seismic network for the period 2004-2005 (Agurto-Detzel et al., 2014). Earthquake focal mechanisms dataset has been built up from the GCMT catalog (Harvard-CMT; Dziewonski et al., 1981; Ekström et al., 2012) merged with data from local temporary seismic networks deployed by Lange et al. (2008) for the period December 2004-November 2005, Agurto et al. (2012) for the period July 2007-February 2008, and Sielfeld et al. (2019) for the March 2014-June 2015 period.

Only intraplate crustal events were analyzed to focus our study on upper plate deformation (Fig. 4). For purposes of regional stress inversion, intraplate focal mechanisms were sorted in seismic regions based on geographic clusters (Figs. 4, 5), where calculated stresses appear homogeneously distributed (for the methodology of stress inversion see e.g., Petit et al., 1996; Sue et al., 1999; Delacou et al., 2004; Lacombe et al., 2006; Delvaux and Barth, 2010). We computed the reduced stress tensor inversions by using the grid-search Rotational Optimization function implemented in TENSOR software (Delvaux and Sperner, 2003). Further details on the database of focal mechanisms and methodological aspects of formal stress inversion are provided in

\section{Supporting Information 1.}

\section{SEISMICITY DISTRIBUTION AND STRESS REGIME}

\subsection{Seismicity distribution from global and local seismic networks}

The global database of the USGS catalog for the last $\sim 40$ years consists of around 600 shallows events with a depth $<70 \mathrm{~km}$ (Fig. 1), and moderate- to high- magnitudes $\left(\mathrm{M}_{W}\right.$ and $\left.\mathrm{M}_{L}\right)>3,70 \%$ of the data being concentrated in the range of magnitude between 4 and 5. The along-strike spatial distribution of the shallow earthquakes in the Patagonian Andes is heterogeneous, with a strong concentration north of the CTJ, where intraplate seismicity is mainly hosted along the trace of the Liquiñe-Ofqui fault system (LOFS), as already evidenced by temporal local seismic networks (Lange et al., 2008; Agurto et al., 2012; Sielfeld et al., 2019).

Seismic record is disrupted south of the CTJ by a $470-450 \mathrm{~km}$ gap between $46.5^{\circ}$ and $50.2^{\circ} \mathrm{S}$ (Fig. 2). Within the northern segment of this gap, Agurto-Detzel et al. (2014) detected 274 events with a local seismic network (uncertainty location $<20 \mathrm{~km}$ ) for the 
period 2004-2005. No events from the Wadati-Benioff zone were detected, while intraplate earthquakes are less than $10 \mathrm{~km}$ deep, showing magnitude $\left(M_{L}\right)$ ranging between 0.5-3.4. These events are associated with volcanoes, spatially located close to the LOFS, glacier calving, and mining activities (Agurto-Detzel et al., 2014). South of $50.2^{\circ} \mathrm{S}$, scarce intraplate seismicity is registered, located in the structural domain of the fold-and-thrust belt.

\subsection{Earthquakes focal mechanisms and stress tectonic regime}

From the collection of available earthquake focal mechanisms of intraplate seismicity, we analyzed the variations of stress regime along the Patagonian Andes in seismic regions north and south of the CTJ (Figs. 4, 5).

\subsubsection{North of the Chile Triple Junction}

Intraplate seismicity north of the CTJ is nested along the main trace and secondary branches of the Liquiñe-Ofqui fault system (LOFS). We sub-divided the seismicity into three seismic regions, from north to south (Figs. 4, 5): La Araucania (38 $40^{\prime}-39^{\circ} 50^{\prime S}$ ), Los Lagos ( $\left.41^{\circ} 40^{\prime}-43^{\circ} 20^{\prime} S\right)$, and Aysén ( $\left.44^{\circ}-46^{\circ} S\right)$.

The focal mechanisms show mainly strike-slip kinematics (Fig. 5). Indeed, the strike-slip faulting mode prevails within all the seismic regions with similar frequency values of 64 to $68 \%$ (Fig. 5). The focal mechanisms depth range between 4 and $21 \mathrm{~km}$ and their magnitude is between 1.5 and $6 M_{W}$. Among these events, a seismic swarm (mainshock $\left.M_{W}=6.2\right)$ took place in April 2007 in the Aysén fjords triggering destructive landslideinduced tsunamis (Mora et al., 2010; Sepúlveda et al., 2010; Agurto et al., 2012).

The computed reduced stress tensors exhibit a strike-slip stress regime in all these three regions, with ENE-WSW- to NE-SW-oriented maximum horizontal compressional stress (SHmax) and SSE-NNW- to SE-NW-oriented minimum horizontal compressional stress (Shmin) (Table 1; Fig. 5). The horizontal compressional stress axes are therefore slightly oblique to the continental margin that strikes $\sim \mathrm{N} 10^{\circ}$. It should be noted that focal mechanisms of strike-slip faulting mode prevail, forming around two-thirds of the total population (Fig. 5). For such reason, each group of focal mechanisms (SS, NF, and TF) 
does not have equal weight during stress inversion, inducing an uncertainty potential in the orientation of stress axes.

\subsubsection{South of the Chile Triple Junction}

Between $46.5^{\circ} \mathrm{S}$ and $50^{\circ} \mathrm{S}$, no earthquake fault-plane solutions have been reported because of the seismicity gap. South of $50^{\circ} \mathrm{S}$, only a few focal mechanisms have been recorded in the Última Esperanza seismic region by the GCMT global catalog ( $n=4$; Fig. 5) with magnitudes of $\sim 5 \mathrm{Mw}$, and focal depths of $\sim 12-15 \mathrm{~km}$. The quality of the computed reduced stress tensor is indeed relatively poor due to the scarcity of the data. However, the faulting is homogeneous depicting N-S-oriented thrust faults (Ghiglione et al., 2019) associated with a compressive stress regime and $\sim$ E-W-trending SHmax $\left(\mathrm{N}^{\circ} 9^{\circ}\right)$ (Table 1; Fig. 5).

\section{DISCUSSION}

Northward migration of the CTJ to its present-day position determined the current subduction configuration along the western margin of Patagonia. The direction of convergence between the Nazca and Antarctica oceanic plates and South America estimated by global plate motion models (NUVEL-1A, DeMets et al., 1990, 1994) appears roughly subparallel to the orientation of the SHmax obtained for each region (Fig. 5). It reveals first-order control by plate boundary forces (Zoback, 1992; Heidbach et al., 2007). It should be noted that SHmax orientation north of CTJ has a 17 to $36^{\circ}$ counter-clockwise rotation concerning the Nazca plate convergence direction (Fig. 5). This result is consistent with numerical models showing the counter-clockwise rotation of main axes of stress regarding the convergence vector along the master fault of the LOFS (Nelson et al., 1994; Iturrieta et al., 2017).

Since plate boundary forces exert the main control on the crustal stress field along the Patagonian Andes, variations of both seismicity distribution and tectonic stress regime are expected north and south of the CTJ. North of the CTJ, a strike-slip tectonic stress regime prevails, compatible with long- and short-term dextral shearing along the LOFS (Figs. 5, 6; Dewey and Lamb, 1992; Cembrano et al. 2002; Thomson, 2002; Cembrano and Lara, 2009). This crustal discontinuity plays a major role in controlling the intraplate (brittle) deformation (Lange et al., 2008; Agurto et al., 2012; Sielfeld et al., 2019), 
producing a high kinematic complexity (Hernandez-Moreno et al., 2014). On the other hand, $\sim E-W$ compression that seems to reactivate the Patagonian fold and thrust belt in the Antarctic plate realm (Figs. 5, 6), is also in agreement with predictions from Nelson et al. (1994).

Both sectors of active seismicity and faulting, along the LOFS and the southern fold-andthrust belt, are disrupted by a $\sim 450-470 \mathrm{~km}$ long intraplate seismic gap (Fig. 2), spatially coincident with the asthenospheric slab window beneath Patagonia (Breitsprecher and Thorkelson, 2009; Russo et al., 2010). In the upper plate above the slab window, the local seismic network data from Agurto-Detzel et al. (2014), only show low-magnitude seismicity $\left(M_{L}<3.4\right)$, related to non-tectonic processes, as glacial calving and mining activities.

Regarding the origin of this seismic gap, we propose that it results from two coeval mechanisms, both related to the South Chile ridge subduction. On one hand, the decrease in convergence velocity that drops from $\sim 8 \mathrm{~cm} / \mathrm{yr}$ to $2 \mathrm{~cm} / \mathrm{yr}$ after the passage of the South Chile ridge, together with the short segment of Antarctic-South America plate interface (<40-45 km by Breitsprecher and Thorkelson, 2009), could reduce the mechanical coupling between plates, and indeed, the amount of stress transmitted to the overriding plate. This potential link between seismicity and coupling along the subduction zone could be further tested by analyzing the shear stresses along megathrust in the subduction zone to estimate the amount of available stress transmitted to the crust (Lamb, 2006; Dielforder et al., 2020). On the other hand, the anomaly in the geothermal gradient (Ávila and Dávila, 2018) weakens the continental crust by reducing the brittle rheological domain, and thus, limiting the seismic potential. This thermal effect is related to the asthenospheric upwelling filling the slab window opening (DeLong et al., 1978; Thorkelson, 1996).

Since there is no report of earthquake focal mechanisms of intraplate between the $46.5^{\circ} \mathrm{S}$ and $50^{\circ} \mathrm{S}$, we are not able to resolve the present-day tectonic stress regime, and therefore, it remains an open question. Additionally, we could look for insights from studies that do not depend on seismicity. For example, morphotectonic analysis in the central region of the Patagonian Andes has suggested normal faulting induced by negative tectonic inversion of relief (Lagabrielle et al., 2007; Scalabrino et al., 2010, 2011). Thus, in this region, the buoyancy related-forces (second-order, regional force) 
such as asthenospheric upwelling and lithospheric thinning could exert the main control on the upper plate stress field (Fig. 6).

\section{CONCLUDING REMARKS}

In this study, we analyze both the seismicity distribution and the associated tectonic stress regime along the Patagonian Andes to address how the subduction of the SCR disturbs the upper plate tectonics. Three seismotectonic settings are identified, as follows:

North of the CTJ, the intraplate seismicity is concentrated along the LOFS. In this area, a strike-slip stress regime with SHmax slightly oblique to the continental margin prevails. South of $50^{\circ} \mathrm{S}$, scarce seismicity in the southernmost foreland of the Southern Patagonian Andes depicts a compressive stress regime with an E-W-oriented maximum horizontal compressional axis. These two sectors of active seismicity are disrupted by a significant seismic gap of $\sim 450-470 \mathrm{~km}$, which lay between $47^{\circ} \mathrm{S}$ and $50^{\circ} \mathrm{S}$. Mechanisms preventing brittle/seismic deformation could be associated with shallow subduction of the Antarctic slab and the weak rheological behavior of the continental crust.

\section{ACKNOWLEDGMENTS}

This research is part of a bilateral scientific cooperation project between Argentinian Mincyt - Universidad de Buenos Aires, and the BesanÇon University, funded by the Argentinian-French ECOS-SUD under grant project A15U02. The scientific results were obtained using Win-Tensor, free-software developed by Dr. Damien Delvaux, Royal Museum for Central Africa, Tervuren, Belgium (http://damiendelvaux.be/Tensor/tensorindex.html). RS is thankful to Andrés Echaurren, Guido Gianni, and Silvana Spagnotto for fructiferous discussions. We are grateful to previous authors for producing the data compiled to perform this contribution. Likewise, thanks to three anonymous reviewers and the Associate Editor Prof. Gerard Roberts for constructive comments helping to improve the article, and the Scientific Editor Carlo Doglioni by editorial handling. 


\section{CONFLICT OF INTEREST STATEMENTS}

The authors declare no known financial or personal interest conflict.

\section{DATA AVAILABILITY STATEMENT}

The data supporting the findings of this study are available in Supporting Information 1 of this article, and within the article "Agurto-Detzel, H., Rietbrock, A., S., Bataille, Miller, M., Iwamori, H. and Priestley, K., 2014. Seismicity distribution in the vicinity of the Chile Triple Junction, Aysén Region, southern Chile. Journal of South American Earth Sciences, 51, 1-11" and "Ávila, P. and Dávila, F.M, 2018. Heat flow and lithospheric thickness analysis in the Patagonian asthenospheric windows, southern South America. Tectonophysics, 747-748, 99-107", and their respective supplementary materials.

\section{REFERENCES}

1. Agurto, H., Rietbrock, A., Barrientos, S., Bataille, K. and Legrand, D., 2012. Seismo-tectonic structure of the Aysén Region, Southern Chile, inferred from the $2007 \mathrm{Mw}=6.2$ Aysén earthquake sequence. Geophysical Journal International, 190, 116-130. doi: 10.1111/j.1365246X.2012.05507.x.

2. Agurto-Detzel, H., Rietbrock, A., S., Bataille, Miller, M., Iwamori, H. and Priestley, K., 2014. Seismicity distribution in the vicinity of the Chile Triple Junction, Aysén Region, southern Chile. Journal of South American Earth Sciences, 51, 1-11.

3. Ávila, P. and Dávila, F.M, 2018. Heat flow and lithospheric thickness analysis in the Patagonian asthenospheric windows, southern South America. Tectonophysics, 747-748, 99-107. https://doi.org/10.1016/j.tecto.2018.10.006.

4. Ávila, P. and Dávila, F.M, 2020. Lithospheric thinning and dynamic uplift effects during slab window formation, southern Patagonia ( $45^{\circ}-55^{\circ}$ S). Journal of Geodynamics, 133, 101689.

5. Bilek, L. S., 2010. Seismicity along the South American subduction zone: Review of large earthquakes, tsunamis, and subduction zone complexity. Tectonophysics, 495, 2-14. doi: http://dx.doi.org/10.1016/j.tecto.2009.02.037.

6. Breitsprecher, K. and Thorkelson, D.J., 2009. Neogene kinematic history of Nazca-AntarcticPhoenix slab windows beneath Patagonia and the Antarctic Peninsula. Tectonophysics, 464(1-4), 10-20. 
7. Bourgois, J., Guivel, C., Lagabrielle, Y., Calmus, T., Boulègue, J. and Daux, V., 2000. Glacialinterglacial trench supply variation, spreading ridge subduction, and feedback controls on the Andean margin development at the Chile triple junction area $\left(45-48^{\circ} \mathrm{S}\right)$. Journal of Geophysical Research, 105, 8355-8386.

8. Bourgois, J., Lagabrielle, Y., Martin, H., Dyment, J., Frutos, J. and Cisternas, M.E., 2016. A Review on Forearc Ophiolite Obduction, Adakite-Like Generation, and Slab Window Development at the Chile Triple Junction Area: Uniformitarian Framework for Spreading-Ridge Subduction. Pure and Applied Geophysics, 173, 3217-3246. https://doi.org/10.1007/s00024-016-1317-9.

9. Cande, S.C. and Leslie, R.B., 1986. Late Cenozoic tectonics of the Southern Chile Trench. Journal of Geophysical Research, 91, 471-496.

10. Cembrano, J., Lavenú, A., Yañez, G., Riquelme, R., García, M., González, G. and Hérail, G., 2007. Neotectonics. In: The Geology of Chile (T. Moreno, and W. Gibbons, eds). Geological Society of London Special Publication, 9, 231-262.

11. Cembrano, J., Lavenu, A., Reynolds, P., Arancibia, G., López, G. and Sanhueza, A., 2002. Late Cenozoic transpressional ductile deformation north of the Nazca-South America-Antarctic triple junction. Tectonophysics, 354, 289-314.

12. Cembrano, J. and Lara, L., 2009. The link between volcanism and tectonics in the Southern Volcanic Zone of the Chilean Andes: A review. Tectonophysics, 471(1-2), 96-113. doi:10.1016/j.tecto.2009.02.038.

13. Delacou, B., Sue, C., Champagnac, J-D. and Burkhand, M., 2004. Present-day geodynamics in the bend of the western and central Alps as constrained by earthquakes analysis. Geophysical Journal International, 158, 753-774.

14. DeLong, S.E., Fox, P.J. and MacDowell, F.W., 1978. Subduction of the Kula Ridge at the Aleutian Trench. Geological Society of America Bulletin, 89, 83-95.

15. DeLong, S.E., Schwarz, W.M. and Anderson, R.N., 1979. Thermal effects of ridge subduction. Earth and Planetary Science Letters, 44, 239-246.

16. Delvaux, D. and Barth, A., 2010. African stress pattern from formal inversion of focal mechanism data. Tectonophysics, 482, 105-128.

17. Delvaux, D. and Sperner, B., 2003. New aspects of tectonic stress inversion with reference to the TENSOR program. In: New Insights into Structural Interpretation and Modelling (D.A. Nieuwland, ed). Geological Society, Special Publications. London, 212, 75-100.

18. DeMets, C., Gordon, R.G., Argus, D.F. and Stein, S., 1990. Current plate motions. Geophysics Journal International, 101, 425-478.

19. DeMets, C., Gordon, R.G., Argus, D.F. and Stein, S., 1994. Effect of recent revisions to the geomagnetic reversal time scale on estimates of current plate motions. Geophysical Research Letters, 21(20), 2191-2194.

20. Dewey, J.F., Lamb, S.H., 1992. Active tectonics of the Andes. Tectonophysics, 205, 79-95.

This article is protected by copyright. All rights reserved 
21. Dielforder, A., Hetzel, R. and Oncken, O., 2020. Megathrust shear force controls mountain height at convergent plate margins. Nature, 582, 225-229.

22. Dziewonski, A.M., Chou, T.-A. and Woodhouse, J.H., 1981. Determination of earthquake source parameters from waveform data for studies of global and regional seismicity. Journal of Geophysical Research, 86, 2825-2852. doi:10.1029/JB086iB04p02825.

23. Echaurren, A., Encinas, A., Sagripanti, L., Duhart, P., Gianni, G. and Folguera, A., 2018. Los Andes Norpatagónicos como ejemplo de un orógeno bivergente. XV Congreso Geológico de Chile, ESEG-1, pp. 1112. Concepción, Chile.

24. Ekström, G., M. Nettles, and A. M. Dziewonski, 2012 The global CMT project 2004-2010: Centroidmoment tensors for 13,017 earthquakes. Physics of the Earth and Planetary Interiors, 200-201, 19. doi:10.1016/j.pepi.2012.04.002.

25. Fosdick, J.C., Romans, B.W., Fildani, A., Bernhardt, A., Calderón, M. and Graham, A., 2011. Kinematic evolution of the Patagonian retroarc fold-and-thrust belt and Magallanes foreland basin, Chile and Argentina, 51 ${ }^{\circ} 30^{\prime}$ 'S. GSA Bulletin, 123(9-10), 1679-1698.

26. Ghiglione, M., Suarez, F., Ambrosio, A., Da Poian, G., Cristallini, E., Pizzio, M. and Reinoso, M., 2009. Structure and evolution of the Austral Basin fold-thrust belt, southern Patagonian Andes. Revista de la Asociación Geológica Argentina, 65(1), 215-236.

27. Ghiglione, M., Ronda, G., Suárez, R.J., Aramendía, I., Barberón, V., Ramos, M.E., Tobal, J., García-Morabito, E., Martinod, J. and Sue, C. 2019. Structure and tectonic evolution of the South Patagonian fold and thrust belt: Coupling between subduction dynamics, climate and tectonic deformation. In: Andean Tectonics (B. Horton, and A. Folguera, eds). Elsevier, Amsterdam, 24, 675-697.

28. González, E., 1989. Hydrocarbon resources in the coastal zone of Chile. In: Geology of the Andes and its Relation to Hydrocarbon and Mineral Resources (G.E. Ericksen, et al., eds). Circum-Pac. Counc. for Energy and Min. Resour. Houston, Texas, 28, 383-404.

29. Gorring, M., Kay, S., Zeitler, P., Ramos, V.A, Rubiolo, D., Fernandez, M. and Panza, J., 1997. Neogene Patagonian plateau lavas: continental magmas associated with ridge collision at the Chile Triple Junction. Tectonics, 16, 1-17.

30. Guillaume, B., Martinod, J., Husson, I., Roddaz, M. and Riquelme, R., 2009. Neogene uplift of central eastern Patagonia: Dynamic response to active spreading ridge subduction? Tectonics, 28, TC2009. doi:10.1029/2008TC002324.

31. Guillaume, B., Moroni, M., Funiciello, F., Martinod, J. and Faccenna, C., 2010. Mantle flow and dynamic topography associated with slab window opening: insights from laboratory models. Tectonophysics, 496(1-4), 83-98.

32. Heidbach, O., Reinecker, J., Tingay, M., Müller, B., Sperner, B., Fuchs, K. and Wenzel, F., 2007. Plate boundary forces are not enough: Second- and third-order stress patterns highlighted in the World Stress Map database. Tectonics, 26, 1-19. doi:10.1029/2007TC002133.

This article is protected by copyright. All rights reserved 
33. Hernandez-Moreno, C., Speranza, F. and Di Chiara, A., 2014. Understanding kinematics of intraarc transcurrent deformation: Paleomagnetic evidence from the Liquiñe-Ofqui fault zone (Chile, 38-41오). Tectonics, 33, 1964-1988. doi:10.1002/2014TC003622.

34. Iturrieta, P., Hurtado, D., Cembrano, J. and Stanton-Yonge, A., 2017. States of stress and slip partitioning in a continental scale strike-slip duplex: Tectonic and magmatic implications by means of finite element modeling. Earth and Planetary Science Letters, 473, 71-82. doi: 10.1016/j.epsl.2017.05.041.

35. Lacombe, O., Mouthereau, F., Kargar, S. and Meyer, B., 2006. Late Cenozoic and modern stress fields in the western Fars (Iran): Implications for the tectonic and kinematic evolution of central Zagros. Tectonics, 25, 1003. doi: 10.1029/2005TC001831.

36. Lagabrielle, Y., Suarez, M., Malavieille, J., Morata, D., Espinoza, F., Maury, R., Scalabrino, B., de la Cruz, R., Rossello, E., Barbero, L.M. and Bellon, H., 2007. Pliocene extensional tectonics in Eastern Central Patagonian Cordillera: geochronological constraints and new field evidence. Terra Nova, 19, 413-424.

37. Lamb, S., 2006. Shear stresses on megathrusts: Implications for mountain building behind subduction zones. Journal of Geophysical Research, 111, B07401. doi:10.1029/2005JB003916.

38. Lange, D., Cembrano, J., Rietbrock, A., Haberland, C., Dahm, T. and Bataille, K., 2008. First seismic record for intra-arc strike-slip tectonics along the Liquiñe-Ofqui fault zone at the obliquely convergent plate margin of the Southern Andes. Tectonophysics, 455(14-24). doi:10.1016/j.tecto.2008.04.014.

39. Levin, B.W. and Sasorova, E.V., 2009. Latitudinal distribution of earthquakes in the Andes and its peculiarity. Advances in Geosciences, 22, 139-145.

40. Mora, C., Comte, D., Russo, R., Gallego, A. and Mocanu, V., 2010. Aysén seismic swarm (January 2007) in southern Chile: analysis using Joint Hypocenter Determination. Journal of Seismology, 14, 683-691. doi: 10.1007/s10950-010-9190-y.

41. Müller, R.D., Seton, M., Zahirovic, S., Williams, S.E., Matthews, K.J., Wright, N.M., Shephard, G.E., Maloney, K.T., Barnett-Moore, N., Hosseinpour, M., Bower, D.J. and Cannon, J., 2016. Ocean Basin Evolution and Global-Scale Plate Reorganization Events Since Pangea Breakup. Annual Review of Earth and Planetary Sciences, 44. doi: 10.1146/annurev-earth-060115-012211.

42. Nelson, E., Forsythe, R. and Arit, I., 1994. Ridge collision tectonics in terrane development. Journal of South America Earth Sciences, 7, 271-278.

43. Orts, D.L., Folguera, A., Encinas, A., Ramos, M., Tobal, J. and Ramos, V.A., 2012. Tectonic development of the North Patagonian Andes and their related Miocene foreland basin $\left(41^{\circ} 30^{\prime}-\right.$ 43오). Tectonics, 31, 3012. doi:10.1029/2011TC003084

44. Pedoja, K., Regard, V., Husson, L., Martinod, J., Guillaume, B., Fucks, E., Iglesias, M. and Weill, P., 2011. Uplift of quaternary shorelines in eastern Patagonia: Darwin revisited. Geomorphology, $127,121-142$.

This article is protected by copyright. All rights reserved 
45. Perucca, L. and Bastias, H., 2008. Neotectonics, Seismology and Paleoseismology. In: The Late Cenozoic of Patagonia and Tierra del Fuego (J. Rabassa, ed). Developments in Quaternary Sciences, 11(5), 73-94. doi: https://doi.org/10.1016/S1571-0866(07)10005-1

46. Petersen, M.D., Harmsen, S.C., Jaiswal, K.S., Rukstales, K.S., Luco, N., Haller, K.M., Mueller, C.S. and Shumway, A.M., 2018. Seismic Hazard, Risk, and Design for South America. Bulletin of the Seismological Society of America, 108(2), 781-800. doi: 10.1785/0120170002

47. Petit, C., Deverchere, J., Houdry, F., Sankov, V.A., Melnikova, V. I. and Delvaux, D., 1996. Present-day stress field changes along the Baikal rift and tectonic implications. Tectonics, 16(6), 1171-1191.

48. Ramos, M., Suárez, R.J., Boixart, G., Ghiglione, M.C. and Ramos, V.A., 2019. The structure of the northern Austral Basin: Tectonic inversion of Mesozoic normal faults. Journal of South American Earth Sciences, 94, 102195.

49. Ramos, V. and Kay, S.M., 1992. Southern Patagonian plateau basalts and deformation: backarc testimony of ridge collisions. Tectonophysics, 205(1-3), 261-282.

50. Russo, R.M., VanDecar, J.C., Comte, D., Mocanu, V.I., Gallego, A. and Murdie, R.E., 2010. Subduction of the Chile Ridge: Upper mantle structure and flow. GSA Today, 20(9), 4-10. doi: 10.1130/GSATG61A.1

51. Scalabrino, B., Ritz, J.-F. and Lagabrielle, Y., 2011. Relief inversion triggered by subduction of an active spreading ridge: Evidence from glacial morphology in Central Patagonia. Terra Nova, 23(2), 63-69. doi:10.1111/j.1365-3121.2010.00981.x.

52. Scalabrino, B., Lagabrielle, Y., Malavieille, J., Dominguez, S., Melnick., D., Espinoza, F., Suarez, M. and Rossello, E., 2010. A morphotectonic analysis of Central Patagonian Cordillera. Negative inversion of the Andean belt over a buried spreading center? Tectonics, 29, 2. doi: 10.1029/2009TC002453.

53. Sepúlveda, S.A., Serey, A., Lara, M., Pavez, A. and Rebolledo, S., 2010. Landslides induced by the April 2007 Aysén Fjord earthquake, Chilean Patagonia. Landslides, 7, 483-492.

54. Santibañez, I., Cembrano, J., García-Pérez, T., Costa, C., Yáñez, G., Marquardt, C., Arancibia, G. and González, G., 2019. Crustal faults in the Chilean Andes: geological constraints and seismic potential. Andean Geology, 46(1), 32-65. doi: 10.5027/andgeoV46n1-3067

55. Sielfeld, G., Lange, D. and Cembrano, J., 2019. Intra-arc Crustal Seismicity: Seismo-tectonic Implications for the Southern Andes Volcanic Zone, Chile. Tectonics, 38(2). doi: 10.1029/2018TC004985.

56. Somoza, R. and Ghidella, M.E., 2012. Late Cretaceous to recent plate motions in western South America revisited. Earth and Planetary Science Letters, 331-332, 152-163. doi: https://doi.org/10.1016/j.epsl.2012.03.003.

57. Stern, C.R., 2004. Active Andean volcanism: its geologic and tectonic setting. Revista Geológica de Chile, 31(2), 161-206.

This article is protected by copyright. All rights reserved 
58. Sue, C., Thouvenot, F., Fréchet, J. and Tricart, P., 1999. Widespread extension in the core of the western Alps revealed by earthquake analysis. Journal of Geophysical Research, 104(B11), 611622.

59. Tassara, A. and Echaurren, A., 2012. Anatomy of the Andean subduction zone: three-dimensional density model upgraded and compared against global-scale models. Geophysical Journal International, 189, 161-168.

60. Tebbens, S.F., Cande, S.C., Kovacs, L., Parra, J.C., LaBrecque, J.L. and Vergara, H., 1997. The Chile ridge: A tectonic framework. Journal of Geophysical Research: Solid Earth, 102(B6), 1206112084.

61. Thomson, S.N., 2002. Late Cenozoic geomorphic and tectonic evolution of the Patagonian Andes between latitudes $428 \mathrm{~S}$ and 468S: An appraisal based on fission-track results from the transpressional intra-arc Liquiñe-Ofqui fault zone. GSA Bulletin, 114, 1159-1173.

62. Thorkelson, D.J., 1996. Subduction of diverging plates and the principles of slab window formation. Tectonophysics, 255, 47-63.

63. Zoback, M.L., 1992. First and second order patterns of stress in the lithosphere: the World Stress Map Project. Journal of Geophysical Research: Solid Earth, 97, 11703-11728.

\section{FIGURE CAPTIONS}

Figure 1. Plate configuration along the western margin of Patagonia, earthquakes spatial distribution, and main features of the sea-floor fabric (based on Cande and Leslie, 1986; Breitsprecher and Thorkelson, 2009). The inset in the left-superior corner shows the location of the study area, and the sea-floor age (Müller et al. 2016). The pink lines indicate the present-day projection at the surface of the extension of the Patagonia slab window at depth (Breitsprecher and Thorkelson, 2009). Colored circles indicate the earthquakes (USGS catalog) that occurred at a depth $\leq 70 \mathrm{~km}$ and $\mathrm{M} \geq 3$, during the last 40 years. $\mathrm{FZ}=$ fracture zone. $\mathrm{CTJ}=$ Chile Triple Junction.

Figure 2. Horizontal (A) and vertical (B) distribution of the seismicity along the Patagonian Andes. On the right panel, E-W schematic cross-sections were created North and South of the CTJ, and the earthquake hypocenters were projected onto the vertical sections. From these cross-sections, seismic events from the Wadati-Benioff zone and the overriding plate can be discriminated. Note that the intraplate seismic gap between $47^{\circ}-50^{\circ} \mathrm{S}$ matches well with the present-day region of high-heat flow (taken from Ávila and Dávila, 2018). Tectonic structures from the arc-retroarc system in the section $x-x^{\prime}$ are 
based on Orts et al. (2012), y-y' from Ghiglione et al. (2019) and Ramos et al. (2019), and z-z' from Ghiglione et al. (2009) and Fosdick et al. (2011). Structures of the forearctrench system are based on González (1989) and Echaurren et al. (2018). The top of the slab on the cross-sections is drawn according to Breitsprecher and Thorkelson (2009) south of the CTJ and by Tassara and Echaurren (2012) north of the CTJ. CTJ= Chile Triple Junction.

Figure 3. Seismicity distribution around the Chile Triple Junction from global (USGS catalog) and local records (Agurto-Detzel et al., 2014). The local record (Agurto-Detzel et al., 2014) shows no $M_{L}>4$, and earthquakes mainly are related to non-tectonic processes. Black triangles indicate the location of seismic stations. CTJ= Chile Triple Junction. GC= Glaciar calving. GC-BA= General Carrera-Buenos Aires. LOFS= LiquiñeOfqui fault system. O-SM= O’higgins-San Martín.

Figure 4. Intraplate earthquake focal mechanisms along the Patagonian Andes. In the beachball plots, the white field depicts contraction and the colored field depicts extension. GC-BA $=$ General Carrera-Buenos Aires. LOFS= Liquiñe-Ofqui fault system.

Figure 5. A) Maximum horizontal stress (SHmax) orientations of intraplate earthquake focal mechanisms. Each focal mechanism is classified according to the stress regime index (R') proposed by Delvaux and Sperner (2003) in normal faulting (NF; green dots), strike-slip faulting (SS; orange dots), or inverse faulting (TF; red dots). Red and green arrows depict the SHmax and Shmin, respectively, and the length corresponds to the stress relative magnitude. B) Stereoplots (lower-hemisphere, equal-area) with the solution of the reduced stress tensor and corresponding histograms of faulting classes. Principal stress axes are represented, as follows: yellow circle into a circle for $\sigma_{1}$, yellow circle into a square for $\sigma_{2}$, and yellow circle into a triangle for $\sigma_{3}$. CTJ= Chile Triple Junction.

Figure 6. Lithospheric-scale schematic cartoons showing along-strike variations of tectonic stress regime related to the pre-, syn-, and post-stages of South Chile ridge interaction with the Patagonian trench. Red arrow= SHmax. Green arrow= Shmin. CTJ= Chile Triple Junction. LAB= Lithosphere-asthenosphere boundary. LOFS= Liquiñe-Ofqui fault system. 


\section{TABLES}

Table 1. Parameters of the reduced stress tensors. $S S=S t r i k e-s l i p . T F=$ Thrust faulting. $\mathrm{NF}=$ Normal faulting. $\mathrm{R}=$ Stress ratio. $\mathrm{Q}=\mathrm{Quality}$ rank.

\section{SUPPORTING INFORMATION}

Supporting information 1. Methodology, procedure, and database of focal mechanisms employed to compute the reduced stress tensor in each seismic region. 


\begin{tabular}{|c|c|c|c|c|c|c|c|c|c|c|c|c|}
\hline \multirow{3}{*}{$\begin{array}{c}\text { Seismic } \\
\text { regions }\end{array}$} & \multirow{3}{*}{$\mathrm{n}$} & \multicolumn{11}{|c|}{ Data obtained from TENSOR } \\
\hline & & \multicolumn{2}{|c|}{$\sigma 1$} & \multicolumn{2}{|c|}{$\sigma 2$} & \multicolumn{2}{|c|}{$\sigma 3$} & \multicolumn{2}{|c|}{$\alpha$} & \multirow{2}{*}{$\mathrm{R}$} & \multirow{2}{*}{$Q$} & \multirow{2}{*}{ Tectonic regime } \\
\hline & & plunge & Azimuth & plunge & Azimuth & plunge & Azimuth & WMMA & \pm & & & \\
\hline $\begin{array}{c}\text { La } \\
\text { Araucania }\end{array}$ & 29 & 2 & 243 & 80 & 142 & 10 & 333 & 49.2 & 43.7 & 0.64 & C & SS \\
\hline Los Lagos & 12 & 0 & 57 & 84 & 150 & 6 & 327 & 18.9 & 14.7 & 0.54 & $\mathrm{~B}$ & SS \\
\hline Aysén & 22 & 20 & 44 & 70 & 229 & 2 & 134 & 28.8 & 25.4 & 0.13 & $\mathrm{C}$ & SS \\
\hline $\begin{array}{c}\text { Última } \\
\text { Esperanza }\end{array}$ & 4 & 16 & 279 & 18 & 14 & 65 & 150 & 2.3 & 1.7 & 0.2 & C & TF \\
\hline
\end{tabular}


Sea floor age (Ma)

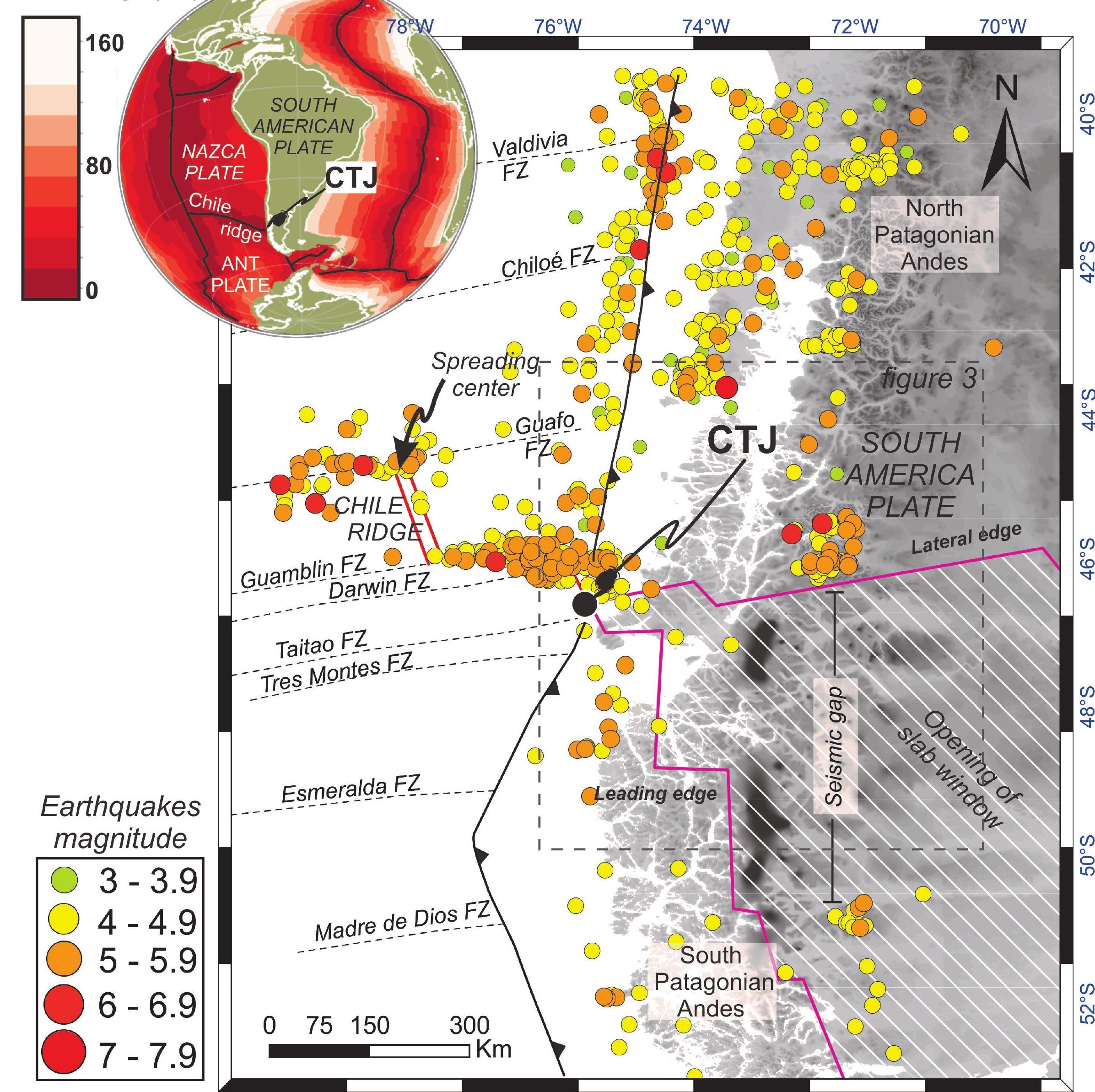



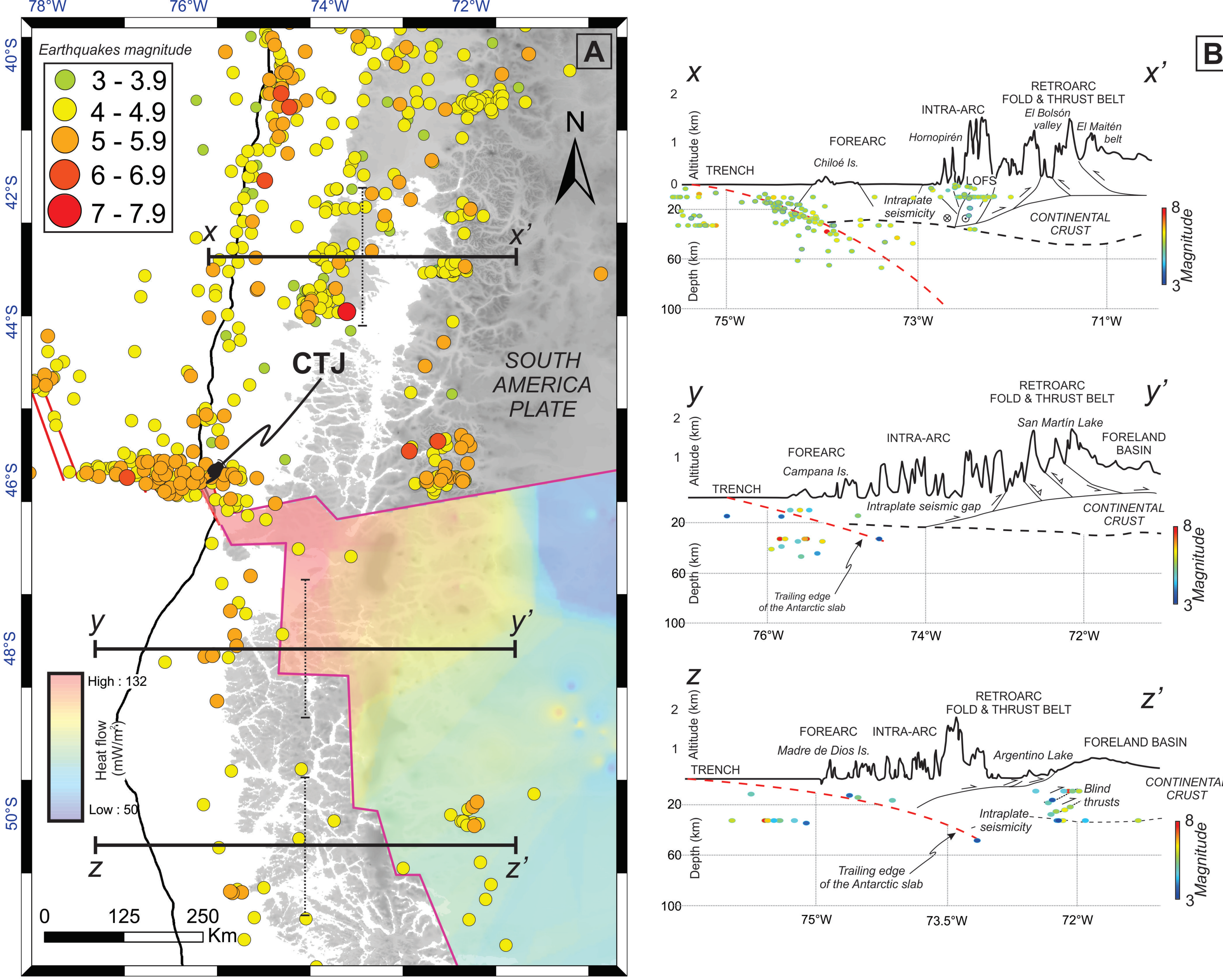


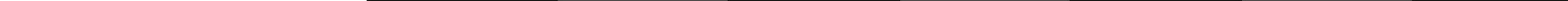




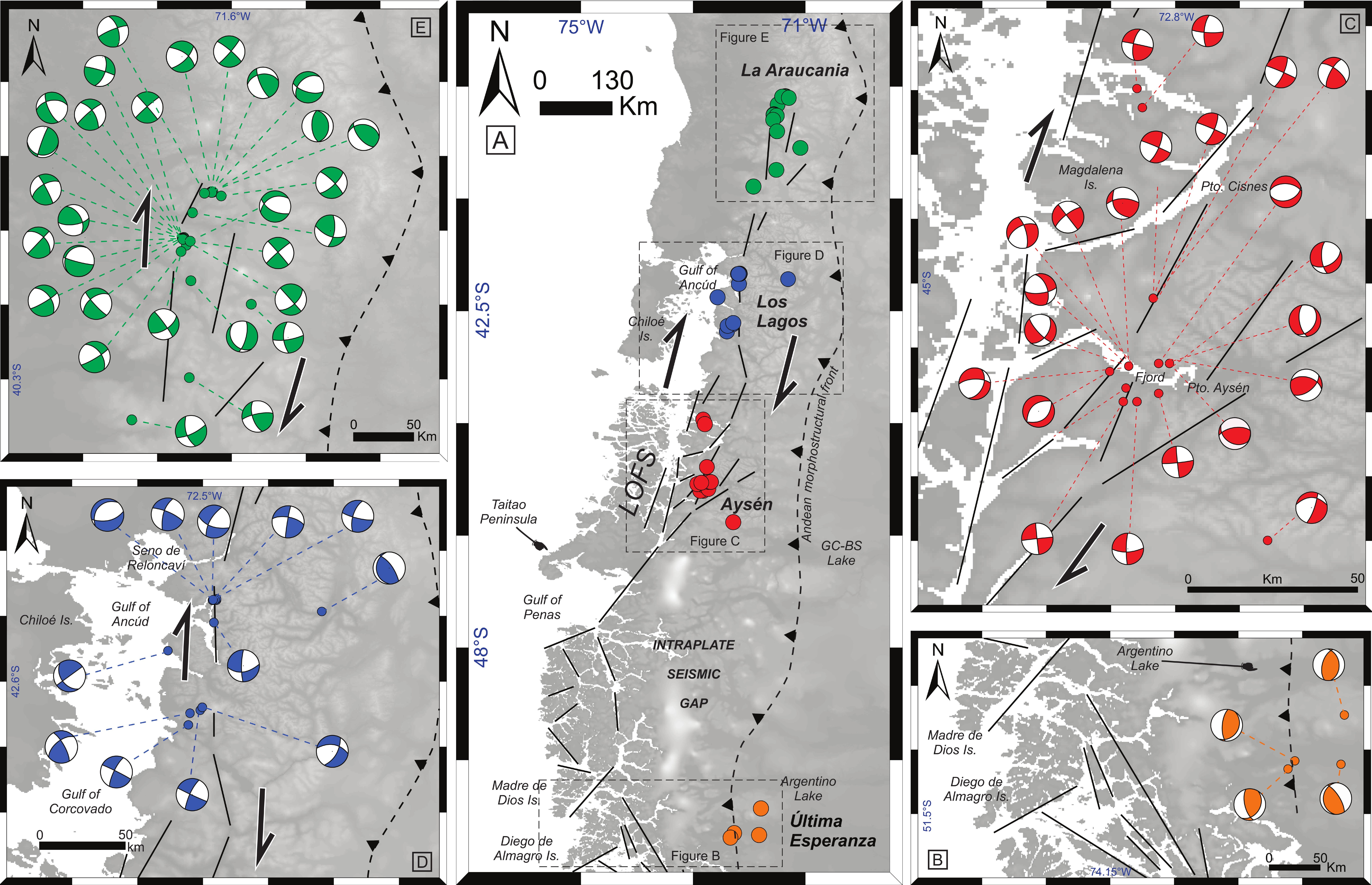



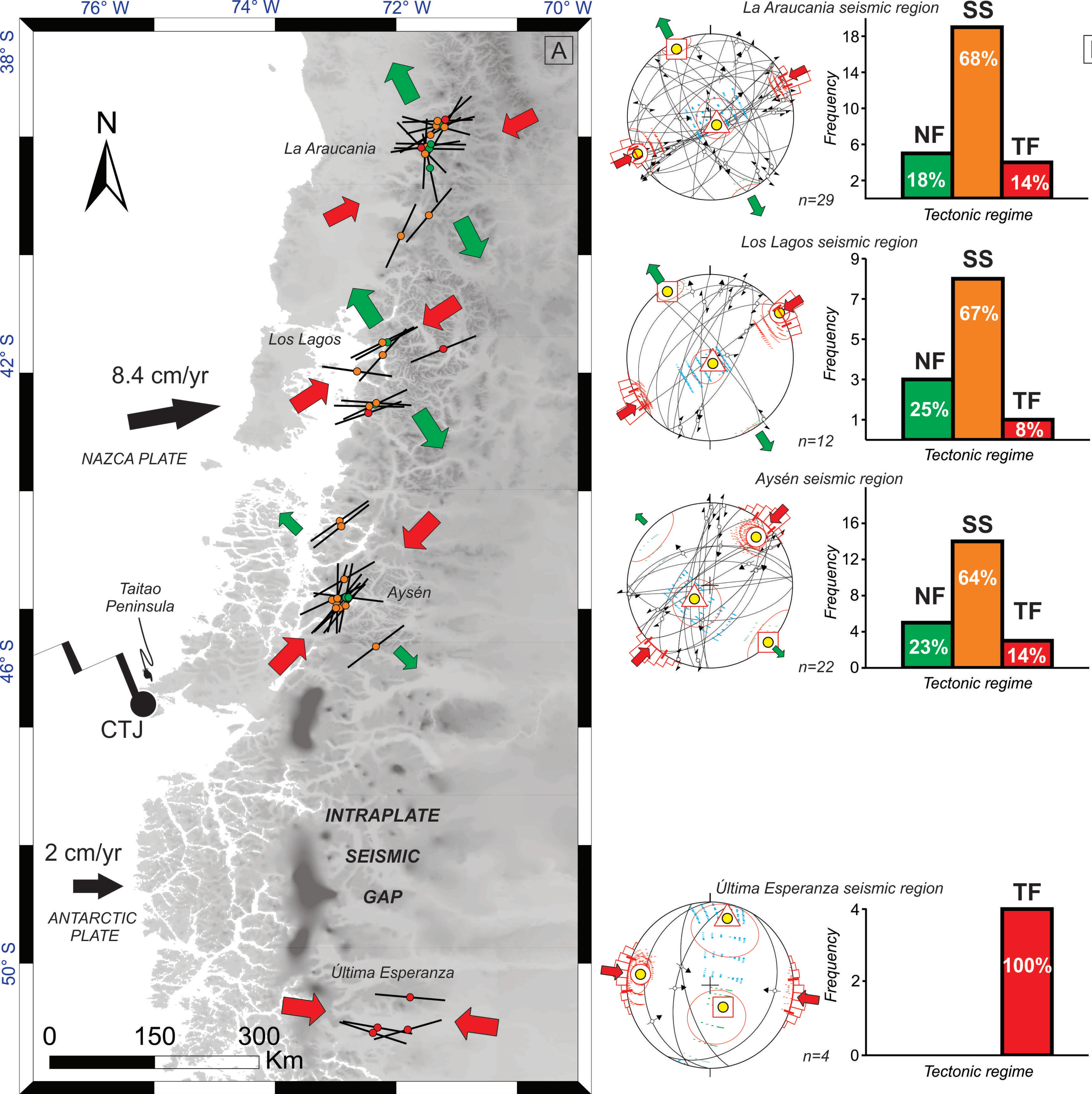

Tectonic regime

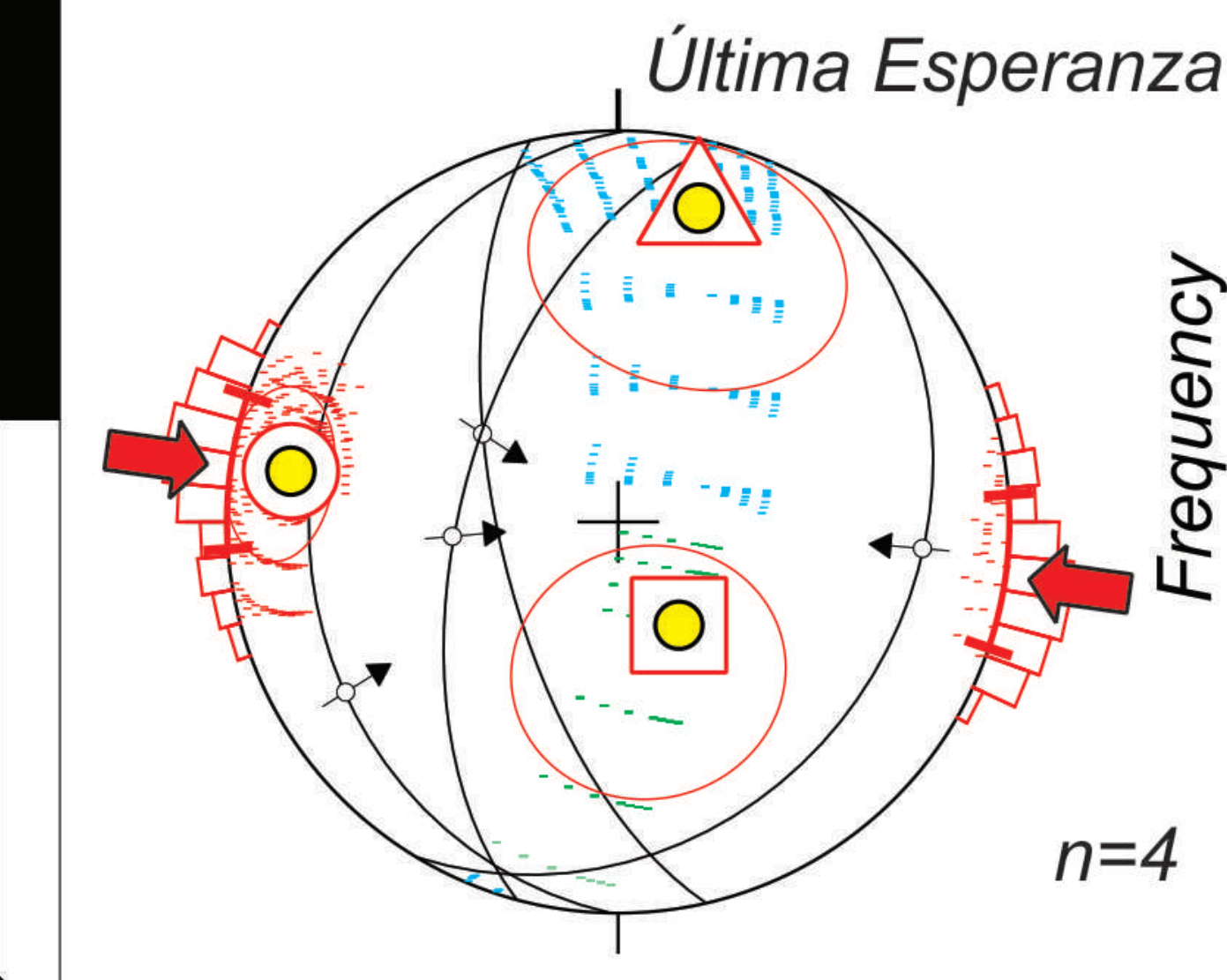

TF
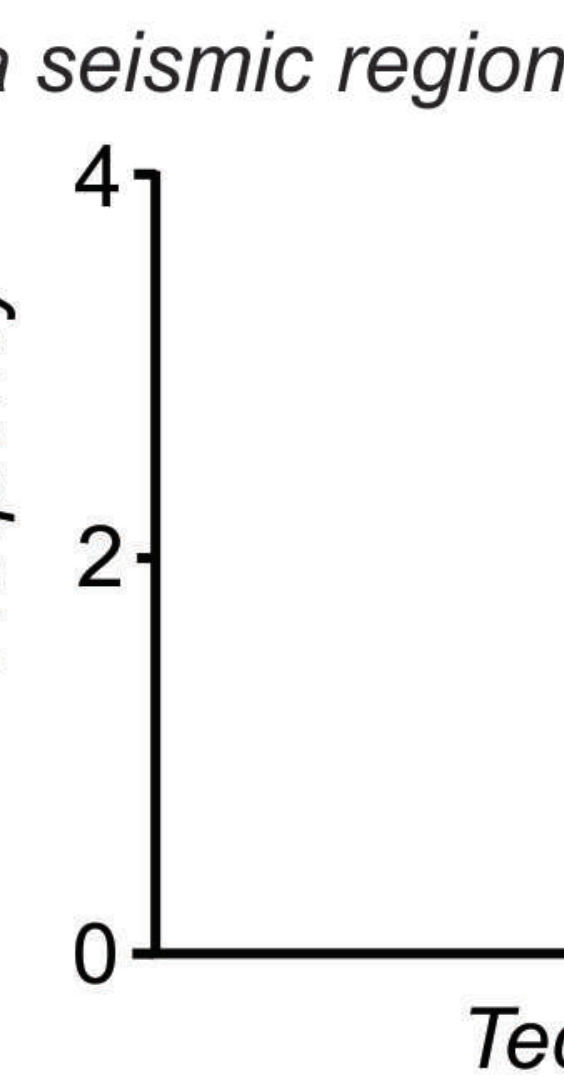

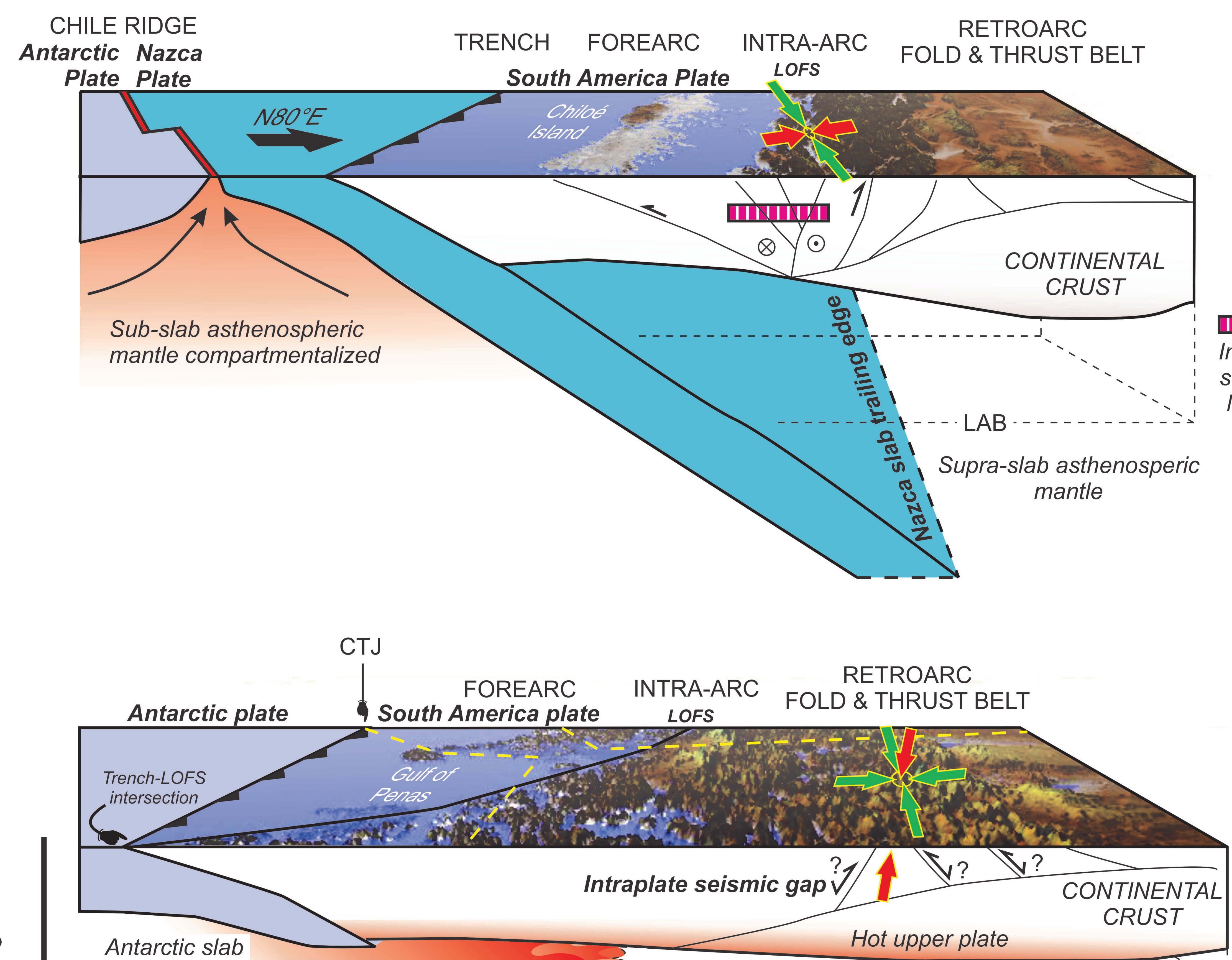

Antarctic slab

Hot upper plate CRUST

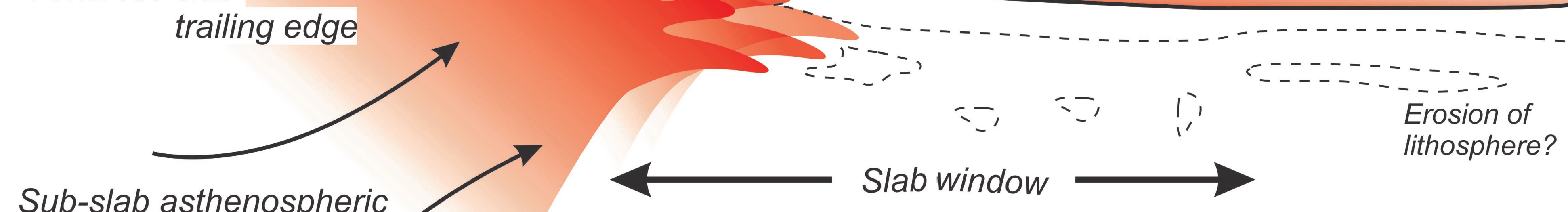

Sub-slab asthenospheric mantle upwelling

TRENCH FOREARC INTRA-ARC

RETROARC FOLD \& THRUST BELT

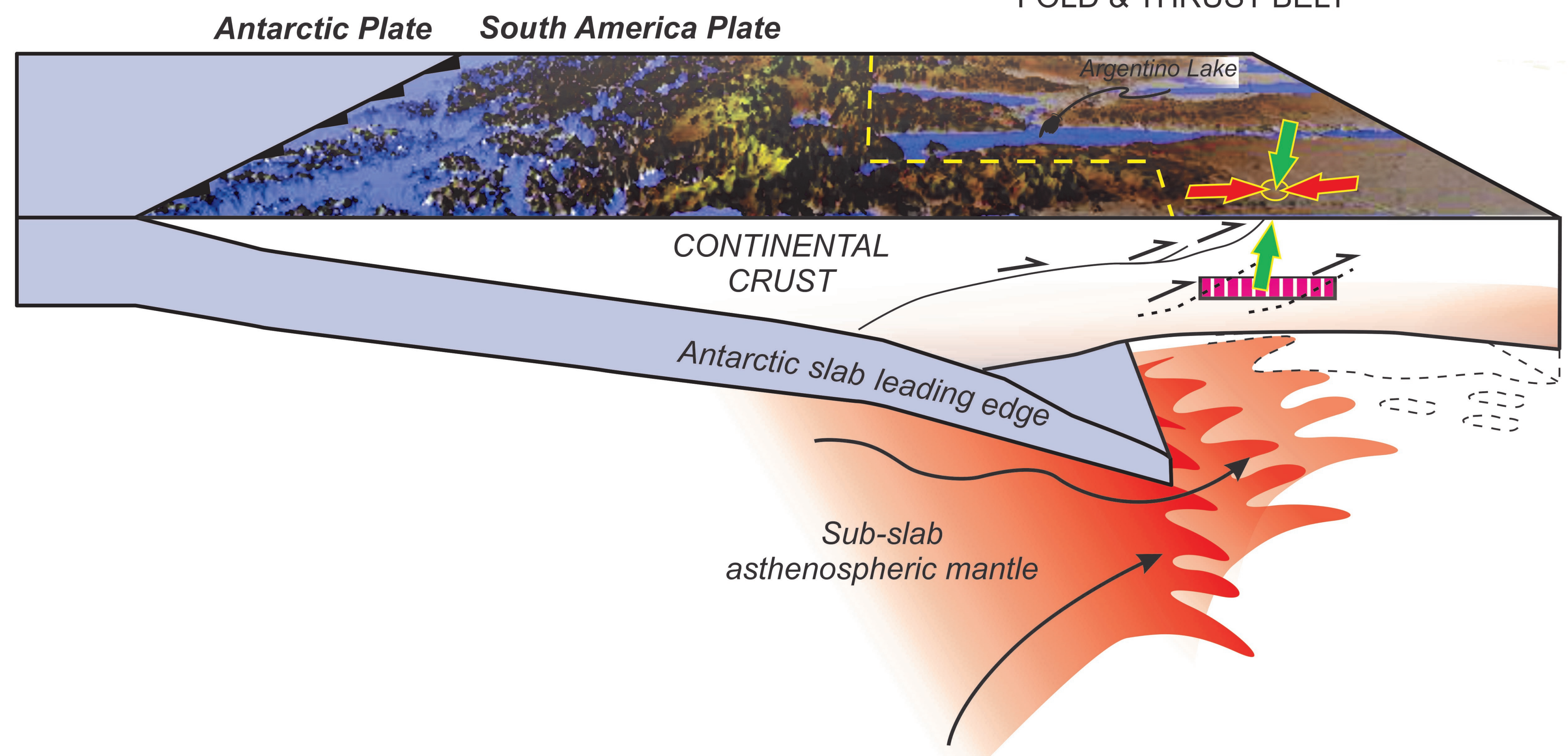

